\title{
Dispute Resolution within the Scope of Health Insurance in the Republic of Slovenia and the USA
}

\author{
Sara Ahlin Doljak, Ph.D. \\ Assist. Prof. at the European Faculty of Law (EVRO-PF), \\ Slovenia and lawyer in Law Firm
}

\begin{abstract}
The article explains the historical development and legal regulation in the Republic of Slovenia and the USA in the field of dispute resolution within the scope of health insurance, which is, however, sub-normalized (insufficient and unregulated) in the Republic of Slovenia. The purpose of the article is to contribute to the future regulation (de lege ferenda) of the considered area in filling the legal vacuums that Slovenian case law senses and perceives in daily trials. More important, however, is the contribution to the out-of-court resolution of health insurance disputes through all forms of alternative dispute resolution (in practice in the last 20 years following the American model), as this certainly contributes to the resolution of social conflicts in this area.
\end{abstract}

Keywords: False Claims Act, dispute resolution, health insurance disputes, mediation

\section{Dispute Resolution In The Republic Of Slovenia}

The Slovenian legal system is characterized by the fact that social security rights are exercised by special administrative procedures of public authorities responsible for social security. Following the entry into force of the Labour and Social Courts Act ${ }^{1}$, the social dispute resolution is in the jurisdiction of specialized social judiciary within the Labour and Social Court in Ljubljana, and the civil proceedings provisions are used in procedures before this court, unless otherwise provided by the Labour and Social Courts Act. The protection of social security rights is a constitutional guarantee of judicial review of any act of public authority by which it interferes with the rights, obligations and legal benefits of individuals, ${ }^{2}$ and of the right to judicial protection ${ }^{3}$ and the international legal standard on the right to judicial protection of civil rights referred to in Article 6 of the European Convention on Human Rights (ECHR). A social dispute takes place between the social security institution (public institute, fund, line ministry) and an individual about the right from the social security system and arises only if the individual does not agree with the final decision of the social security institution and files a claim against it with the competent court. ${ }^{4}$ The Labour and Social Courts Act defines a social dispute according to the jurisdiction of a social court. Such jurisdiction is also given in disputes in the field of health insurance, as well as in disputes regarding liability for damage caused by the health institution to the insured person or for the damage caused to the institution in connection with the insurance case.

Disputes before courts in the field of health insurance are rare and too formal and slow; therefore, organizations have begun to be developed, which offer people an alternative. Nowadays, an alternative to court procedures is mediation, arbitration, mediation-arbitration, conciliation, negotiation, reconciliation, ombudsman, crisis intervention, advocacy, mini-trial, summary jury trial and some other forms. Mediation is becoming a leading way of resolving conflicts in Slovenia; mediation is a process in which the participants, with the support of the mediator, seek to resolve the dispute by considering the interests of all participants and reach an agreement. It establishes a new culture of conflict resolution among people, where there is no winner or loser, and where the participants (usually the parties to the dispute) take the dispute into their hands and resolve it themselves. In the mediation process, we try to understand both sides, to explore the interests of all parties, and to understand the background of the dispute. In the creative process of finding a new solution, we try to find a way to satisfy the interests of all parties. Although a judge decides on a dispute in court, who understands the arguments of all parties, in the end someone is a winner and someone else is a loser; therefore, too often such dispute resolution ends with a new lawsuit. Even when the judgement is final, there is often a sense of deprivation at least on one side.

\footnotetext{
1 ZDSS-1.

${ }^{2}$ Constitution of the Republic of Slovenia on Administrative Disputes, Article 157.

${ }^{3}$ Constitution of the Republic of Slovenia, Article 23.

${ }^{4}$ according to J. Novak, 2004, pp. 1-110
} 
As stated earlier, mediation is a way of resolving disputes with the help of a neutral third person - the mediator. Undoubtedly, mediation in health care offers a range of new ways of resolving conflicts, disagreements and disputes that are an integral part of healthcare work. In Slovenia, the Association of Health Institutes of Slovenia is actively involved in introducing mediation in the field of health care. ${ }^{5}$ Within the Association, a mediator is available to all members of the Association involved in various disputes. Mediation is performed at the head office of the Association of Health Institutes of Slovenia or outside it.

Disputes in health care have some points in common with disputes that occur in other activities, but the causes are different because they are disputes in the process of diagnosis and treatment. Patients are usually burdened and vulnerable due to illness. They often have to reveal very personal problems in healthcare facilities. At the same time, patients' expectations for excellent and quality healthcare services are very high and rarely tolerate minor errors. The quality of healthcare services is linked to the overload of healthcare professionals and stress at work. All of the above causes conflicts.

Mediation in the field of health care in the Republic of Slovenia was enacted by the Patient Rights Act in $2008,{ }^{6}$ and is regulated in more detail by the Rules on healthcare mediation. ${ }^{7}$ The Patient Rights Act regulates mediation in the final stage of the conflict between the patient and the healthcare provider, while the trend is for mediation to be applied earlier, i.e. at all levels of conflicts arising in health care.

Mediation is voluntary. Mediation participants may withdraw their consent at any time during the mediation process and initiate or continue other procedures, including in court or before the Medical Chamber arbitration board. Mediation is free of charge for patients and members of the Medical Chamber and is a confidential process. Usually, already in this conversation, we get to know what bothers them most on the other party. Mediation offers a possibility to begin resolving the dispute immediately. When the parties find an acceptable solution, their agreement is recorded; but if the parties want an enforceable title, such agreement has the same legal force as a final judgement.

There are specific mediation techniques which the mediators learn; however, practical experience is very helpful. These mediation techniques are also very useful in resolving everyday misunderstandings. In the process, each party presents its part of the story, and the mediator ensures that parties do not interrupt each other. By using special techniques, the mediator encourages the parties to hear each other. Different techniques are available to the mediator to encourage the parties to listen and hear each other. It is important to recognize the interests of both parties. Interestingly, they often have common interests, although they did not see them at first. Usually, each party has a pre-made idea of the ideal dispute resolution, but many new solutions arise in the mediation process, that they never thought of before. Strong emotions are often present in disputes. In a controlled way, the mediator allows the parties to express these emotions to a certain extent, so that the parties can continue to discuss solutions. The mediator manages the process in accordance with the principles of the mediation process, whereby it is crucial to be impartial. The mediator does not decide who is guilty and who has acted more or less wrong, but he or she is not the arbitrator in the dispute. The mediator lets the parties to the dispute to make their own decisions, since, after all, it is their dispute. They know best what can satisfy them and what kind of solution they can live with. The mediator only helps them on their way to an agreement.

Mediation is a great alternative to a court procedure. In a court procedure, the parties to the procedure are often frustrated because they cannot fully express their hurt, emotions and feelings, and there is enough time in the mediation process to address human frustration. The judge is only interested in the legally relevant facts. Prolonged court procedures are often monitored by the media, and the black spot on reputation may remain even if the lawsuit was not justified.

${ }^{5}$ Article 1 of the Statute of the Association of Health Institutes of Slovenia stipulates that the association is a community of institutes, which was created on the basis of the Institutes Act with the transformation of the Business Community for Health Care of Slovenia and is its legal successor. The Association of Health Institutes of Slovenia is a legal entity. The members of the Association are public health institutes and other legal entities that perform healthcare activities on the basis of the concession in the territory of the Republic of Slovenia as a major part of their activity and have adopted a decision on joining the Association.

Legal and natural persons engaged in healthcare activities, which are not covered by the previous paragraph or their activity is related to healthcare activity, can participate in the accomplishment of the Association's tasks, but are not members of the Association. Their rights and obligations are determined by contract. The association is a member of the European Association of Hospitals and Other Healthcare Organizations (HOPE) and cooperates with related international organizations.

${ }^{6} \mathrm{ZPacP}$

${ }^{7}$ Rules on healthcare mediation 
Mediation, however, is a confidential process and the dispute is not described in the media, which may affect many people even more. When a patient experiences a doctor listening to him, when he tells the doctor what he was worried about, how he imagined the treatment, and how it affected him because the doctor, according to his perception, did not devote enough time to him to explain the treatment, he becomes more reassured. The doctor also has the opportunity to tell why he acted the way he did and why he could not calm the patient at that moment. The patient may accept this as he sees the doctor as a fallible and ordinary person. There can be "purification" in mediation. During the mediation process, both parties form an agreement on how such events could be prevented in the future.

Mediation is a smart way to resolve a variety of healthcare conflicts: ${ }^{8}$

- between the patient and the healthcare provider;

- between medical staff within a team or between departments;

- between employer and employee;

- between institutes;

- between institutes and their founders;

- between institutes and concessionaires.

\section{Legal sources containing provisions on mediation procedure}

Directive 2008/52/EC of the European Parliament and of the Council of 21 May 2008 on certain aspects of mediation in civil and commercial matters (hereinafter referred to as the Directive) imposes an obligation on Member States to enforce laws, regulations and administrative decisions necessary to comply with the Directive until 21 May 2011. The objectives of the Directive are to facilitate access to alternative dispute resolution and to promote amicable dispute resolution by promoting the use of mediation and by ensuring a balanced relationship between mediation and court procedures. Framework legislation on mediation addresses key aspects of civil procedure. The provisions of the Directive are applicable to mediation in cross-border disputes, but nothing should prevent Member States from applying these provisions to internal mediation procedures.

The Mediation in Civil and Commercial Matters Act (hereinafter referred to as the Mediation Act) was adopted on 23 May 2008. It was published in the Official Gazette on 6 June 2008 and entered into force on 21 June 2008. ${ }^{9}$ The Mediation Act contains the basic principles and rules of the mediation process. It also transposes Directive 2008/52/EC of the European Parliament and of the Council on certain aspects of mediation in civil and commercial matters (hereinafter referred to as the Directive) into the Slovenian legal order. Before 2008, no general regulatory framework existed in Slovenia, but mediation existed in practice since 2001 onwards, mainly as mediation complementing the work of the court. The Mediation in Civil and Commercial Matters Act was drawn up on the basis of the Model Law on International Economic Mediation prepared by UNCITRAL, ${ }^{10}$ which also respected the requirements of the Directive. Since mediation became the subject of legislative regulation after having existed in practice for many years, it was also possible to follow the experience gained in practice.

The Act on Alternative Dispute Resolution in Judicial Matters (ZARSS), ${ }^{11}$ adopted in November 2009, contains specific provisions on mediation offered to parties to court procedures by the courts. It imposes an obligation on all first and second instance courts to offer mediation to all parties in civil, commercial, family and labour disputes. Courts may also offer other types of alternative dispute resolution. ZARSS introduces a special information session. Based on this law, 59 first instance courts (11 district courts, 44 local courts and 4 labour courts) have offered mediation to parties since 15 June 2010, while 5 second instance courts were required to introduce these programs until 15 June 2012. Based on ZARSS, the Rules on mediators in the programs of thecourt and the Rules on awards and reimbursement of travel expenses of mediators, acting in the programs of the courts were adopted. ${ }^{12}$

I have already mentioned that the draft Mediation Act was written on the basis of the UNCITRAL Model Law on International Trade Conciliation. The definitions of "mediation" and "mediator" in the Mediation Act are very similar to the definitions in the Directive. The Model Law also contains both definitions, but the Mediation Act follows the Directive. In terms of scope, the most important difference between the Directive and the Mediation Act is that the Mediation Act applies not only to cross-border disputes but also to internal mediation processes.

\footnotetext{
${ }^{8}$ Mediation, 2015 (e-source).

9 ZMCGZ.

${ }^{10}$ see ZMCGZ, Paragraph 1 of Article 4

11 ZARSS.

12 Rules on awards and reimbursement of travel expenses of mediators, acting in the programs of the courts.
} 
In addition, the principles and rules of the Mediation Act apply not only to civil and commercial matters, but also, mutatis mutandis, to mediation in other disputes, as long as this is consistent with the nature of the legal relationship from which the dispute originates and, if not excluded by law. The Mediation Act exceeds the requirements of the Directive when it comes to confidentiality. It regulates various aspects of confidentiality, such as confidentiality within mediation procedures, confidentiality outside mediation proceedings vis-à-vis third parties and the admissibility of the use of evidence in other procedures. The confidentiality of mediation in general is ensured. Disclosure of information is prohibited except in cases specified in the Mediation Act. Parties may reach a different agreement on matters governed by the Mediation Act or exclude the application of a specific provision of the Mediation Act; however, the provision on the effect of mediation on restrictive and prescriptive time limits cannot be excluded (Article 5 of the Mediation Act). Pursuant to Article 16 of the Mediation Act, where the parties reach an agreement with mediation and expressly accept that, before the expiry of a specified time limit or the occurrence of a specifically defined event, no arbitration or court procedures will be initiated with respect to an existing or future dispute, the arbitration tribunal or the court, on appeal by the defendant, must dismiss such action unless the plaintiff proves that otherwise damage and irreparable consequences would arise. The court must dismiss the action, even though mandatory mediation procedures are required before it is enforced.

According to ZARSS, a judge may order an information session, after which the court may decide that the parties should try to resolve their dispute through mediation. The parties have the right to oppose such a decision. In this case, mediation proceedings do not commence, but parties who unjustifiably refuse to use mediation may bear the costs of legal procedures, regardless of their outcome (Article 19 of ZARSS).

The Patient Rights Act $(\mathrm{ZpacP})^{13}$ introduces mediation as a means of resolving disputes between a patient and a healthcare provider. In the event of such disputes, the Commission for the Protection of Patient's Rights offers mediation to parties. Within the framework of the law, the Rules on healthcare mediation were adopted. ${ }^{14}$ These Rules govern the mediation process. They also specify e.g. the conditions under which one can become a mediator in the field of health care and the control mechanisms concerning the provision of mediation services in this field.

In Slovenia, mediation can be facilitated by mediation providers alone or together with mediators of the healthcare provider or other organizations active in the healthcare sector. In Slovenia, disputes in the field of health care can be resolved by mediators who operate outside the healthcare sector. They may act in the context of (their) economic operators or as sole proprietors. In many cases, mediation services for resolving healthcare disputes are provided by the Association of Health Institutes of Slovenia (an interest group of all healthcare providers in the Republic of Slovenia), which is one of the important areas of its work. If a healthcare provider chooses to offer mediation regardless of the Patient Rights Act, the cost of the mediator and his payment are a matter of agreement between the mediator and the mediation participants (mediants).

Mediation contracts, mediation agreements and final mediation agreements are available in Slovenia. Mediation agreements are usually concluded in writing, and the parties are informed of the possibilities to ensure their immediate implementation. In most cases, this is achieved in two ways:

- the agreement is concluded before a notary in the form of a directly enforceable notarial record;

- the agreement is converted into a court resolution in court.

The essence of the agreement, which has the instruments that allow for the legality, is the fact that no potential failure to comply with the agreed commitments needs to be resolved by taking civil action, but the implementation of the agreement can be achieved directly in judicial enforcement proceedings, as required by the Claim Enforcement and Security Act.

In Slovenia, the dispute management system is currently in place at the University Medical Centre Ljubljana, the leading medical institution in the country. In the coming years, other health care institutions in Slovenia will adopt it as a method of conflict resolution.

In order to ensure the quality and reliability of mediation services, the Association of Health Institutes of Slovenia, which trains health mediators, operates in accordance with the standards developed by MEDIOS ${ }^{15}$ - the Association of Mediation Organizations of Slovenia. In order to be admitted to the training, the candidate must have (cumulatively):

- successfully completed basic mediation training (100 lessons);

- successfully completed at least one advanced mediation training of at least 50 lessons (whether or not the training allows for the acquisition of the title);

\footnotetext{
${ }_{13} \mathrm{ZPacP}$

${ }^{14}$ Rules on healthcare mediation

15 Medios, 2015 (e-source).

164
} 
- at least 2 years of experience in active mediation, 10 mediation cases and at least 50 lessons of practical mediation implementation.

In order to receive the title "trainer", the candidate must have completed a training course of 100 lessons.

\section{Dispute Resolution In The Usa}

One of the most important cases considered by the U.S. Supreme Court in 2015 was the case of King v. Burwell. ${ }^{16}$ The lawsuit calls into question the legality of subsidies for low- and middle-income families on health insurance exchanges run by the federal government. If the court ruled in favour of the plaintiff, millions of people in 36 states that did not establish health insurance exchanges could lose their subsidies. As health insurance is now inaccessible to most of the population in these states, their exchanges will no longer be able to operate, resulting in the collapse of the Affordable Health Care Act in a substantial part of the USA. ${ }^{17}$

The whole basis of the King v. Burwell case is one sentence in a 1,700-page court file, hinting at the assumption that subsidies should only be paid to people in the states which set up their own health insurance exchanges. This sentence contradicts the rest of the law, which clearly states that people are eligible for subsidies, regardless of whether they are listed on a stock exchange established by a federal state or a stock exchange established by the federal government. The plaintiff's argument also conflicts with the understanding of all members of the Congress at the time of voting for the law and also the understanding of all the various independent analysts who have evaluated the effect of this law.

\section{Healthcare Dispute Review}

There are many types of important disputes in the USA: ${ }^{18}$

- patient safety lawsuits against hospitals, nursing homes, doctors and other professionals, as well as product liability lawsuits against manufacturers of medicines and medical devices;

- disputes between members of doctor groups (or between a "group" and individual doctors) or between hospitals and doctors and other staff;

- lawsuits stemming from the False Claims Act (FCA) and other lawsuits related to frauds against hospitals, doctors, medicine and medical device manufacturers, pharmacies, suppliers, etc.;

- complex disputes related to mergers and acquisitions or high transactions involving technological and intellectual property;

- payment and reimbursement disputes involving private and government payers and pharmacies, doctors, hospitals and patients;

- contradictions in risk management (including insurance coverage), including problems with liability for injuries and deaths of patients (especially those where lawsuits do not relate to classic medical negligence), and various commercial lawsuits, e.g. in connection with payment disputes or false damage claims.

\section{Needs and concerns at health care disputes}

Many healthcare disputes are individually suitable for resolution outside the court system due to specific needs and concerns, such as:

- concerns about patient privacy and business confidentiality;

- reducing the time and cost involved in disputes in an industry that receives particular economic, political and social pressures regarding cost control;

- timely elimination of disputes that threaten the very existence of participants (e.g., government false charges that could result in criminal exposure and exclusion from contracting with the government, including Medicare and Medicaid);

- managing important relations with investors, lenders, financial analysts, employees/staff, customers, vendors, and other business "partners" that could suffer serious consequences in the event of notorious public disputes;

- maintaining smooth business relationships between the parties to the dispute, especially in the context of business expansion, industry consolidation and the development of new business relationships;

- eliminating business and personal friction between highly trained and highly paid staff who really have "something better to do" (i.e. treat patients and generate revenue) rather than wasting their days in conference rooms and courtrooms with lawyers and administrators;

- particular resistance to public contradiction when educational and religious organizations, often with their own health facilities or playing other important roles in the provision of health services, are at stake;

\footnotetext{
${ }^{16}$ Syllabus, King et al. v. Burwell.Supreme Court of the United States, 2014 (e-source).

${ }_{17}$ Burwell could have gutted Obamacare in 34 states, 2015 (e-source).

18 according to W. K. Mariner, 1999, pp. 1-57 (e-source).
} 
- eliminating patient safety concerns reflected by the requirements of mixed commission standards for conflict management systems.

In mediation, a non-involved, impartial third party can assist the parties involved and their attorneys in effectively understanding the situation and negotiating a solution. It is appropriate for the mediator to ask questions, make comments, state his observations or opinions on the positions of the parties to the dispute and provide advice or suggestions for resolving the dispute. The solution reached through mediation is documented in the form of a binding contract that can be enforced in court. In arbitration, a non-involved, impartial third party will make binding decisions that resolve the dispute and formulate a verdict that can be enforced in court, although this is practically a final decision, as courts even rarely re-rule on arbitration decisions. In both procedures, the mediator or the arbitrator assists the parties involved in exchanging a sufficient amount of evidence and other information to enable a reasoned and fair procedure.

Mediation and arbitration can deal with the specific needs of the parties to the dispute in a healthcare sphere in different ways: ${ }^{19}$

- mediation and arbitration are more private and confidential than court procedures; even the required public disclosure of information on the dispute is better controlled in conducted private procedures than in years of public battle in a courtroom full of journalists and competitors;

- any alternative dispute resolution should lead to a faster solution and thus reduce material costs; at the same time, the proportion of final verdicts should be higher than that of disputes settled within the judicial system;

- alternative dispute resolution permits the use of dispute resolution professionals with the appropriate knowledge to find solutions, and, where appropriate, relevant regulatory, scientific or other expertise on the healthcare topic under consideration may be provided;

- alternative dispute resolution provides an opportunity for thoughtful resolution of emotional and tensed disputes concerning medical errors, patient safety, end of life, bioethics, and staff contradictions;

- mediation can serve as a forum for resolving disputes between multiple parties, who may not be all parties to the dispute.

There are many types of healthcare disputes in the USA which the alternative dispute resolution can positively affect. Below, I mention two types of disputes related to doctors' professional business relationships and cases of healthcare fraud.

Among the most serious disputes which the healthcare industry participants face are charges filed on the basis of the False Claims Act (FCA) ${ }^{20}$ by federal agencies or agencies of the federal states (often filed by individuals) for allegedly fraudulent payments regarding the government health programs that also include Medicare and Medicaid. ${ }^{21}$ The high stakes involved in these cases are one of the important reasons why the parties involved should carefully consider and try to resolve them through mediation.

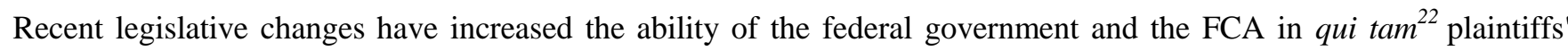
lawsuits to prosecute false claims:

- The PPACA ${ }^{23} \S 6402$ amended the federal Bribery Act and clarified that violations of the Bribery Act can be prosecuted under the FCA.

- The Fraud Enforcement and Recovery Act (FERA) has made the FCA responsible for controlling overpaid payments

${ }^{19}$ G. A. Balcerzak and K. K. Leonhardt, 2008 (e-source).

${ }^{20}$ False Claims Act, 2015 (e-source).

21 The False Claims Act ("FCA") provides, 2015, p. 1 (e-source).

${ }^{22}$ One of the basic principles of criminal and civil law is that no one must benefit from unlawful conduct. Recovery of illegal proceeds is an important element in preventing the investment of the proceeds obtained in this way in criminal activity. It is the duty of the institutions to ensure to the taxpayers the best use of public funds and the effective fight against fraud. The contribution focuses on one such mechanism, known in the English legal system as qui tam. It describes its origin, reasons for the creation and use. The tradition of English qui tam has also left its mark in the USA where the federal law on false claims has been in force since 1863. The qui tam lawsuit constitutes a broader procedural legitimacy through which the American taxpayers can claim on their own behalf and on behalf of the state the amounts appropriated through fraud by the contracting partners of the state. Qui tam, as a special type of popular lawsuit, is especially relevant to the fact that the Republic of Slovenia does not take sufficient measures regarding irregularities in the management of public funds. Since the costs are borne by the private plaintiff, the state can only have a positive income (see M. Pečarič, 2011, pp. 69-86).

${ }^{23}$ Patient Protection andAffordable Care Act, 2015 (e-source). 
and expanding the ability of the Department of Justice (DOJ) to protect subcontractors and agents in addition to employees.

- The PPACA further defined liability for overpayments to ensure that the provider's withholding of overpayments more than 60 days after identification could become a false claim for damages.

The consequences of FCA cases for private operators are potentially catastrophic in the form of monetary, criminal and exclusionary liability. Through mediation agreement, they can avoid (or at least reduce) exclusionary and criminal liability, while evaluating civilian monetary exposure to a known, agreed level. Even where a potential FCA defendant openly (and perhaps correctly) sees a potential claim for damages as eligible, such an approach to mediation and resolution can often have some advantages, inter alia because the defendant can use the solution obtained through mediation to avoid the potentially enormous financial cost of lengthy follow-up investigations, discovery, request for court order and trial, negative impact on relationships and loss of time and energy of senior management and legal staff. From a government perspective, substantial and appropriate financial payments can be recovered without the time lag, risk and expense that accompany the trial to a rich and confident convict. Similarly, governments can devote considerable but limited financial, legal and investigative resources to the cases of healthcare frauds. The solution reached through mediation, may allow government agencies to engage in other important investigations.

When mediation occurs prior to the opening of the plaintiff's FCA complaint, the defendant has the opportunity to defend his interest in privacy, or at least under the minor scrutiny of the public and the media. The defendant's solution to the FCA case will be public and likely to be publicized, but the day after it is announced the investors, lenders, financial analysts, employees, vendors, customers and other key players will look at the case from afar and will no longer continuously investigate the case in the process without a known conclusion. The government is given the opportunity to launch a powerful message that meets the important goal of potentially deterring potential future violators from engaging in illegal activity without incurring further investigation and litigation costs and risk sending a false deterring message if the trial is not concluded in its favour.

The use of mediation in the field of frauds provides a "forum" for resolving contentious issues with multiple parties and agencies. The qui tam solution to cases under the FCA can be a particularly big challenge, since each solution typically involves multiple parties involved, including the HHS Inspector General (who has the administrative authority to exclude a defendant from Medicare), the plaintiff and the defendant. If the defendant seeks relief from liability for overcompensation to Medicaid at any state government, then seeking a solution also requires the involvement of a particularstate's authority, which usually involves the assistant attorney general of the state. Sometimes there are many assistants. Although most attorneys general of the states will require that most FCA-based solutions be approved at various levels of government (the assistant US attorneys and a lawyer usually cannot offer a binding solution), this is rarely a major problem, as approvals at final, "official" higher levels is routinely reached in mediation, thus resolving many types of disputes involving the federal government and governments of federal states and local governments. ${ }^{24}$

Where interrelationships between doctors or doctors and other providers are tensed, a number of lawsuits may follow, including those for loan repayment, breach of non-compete, non-restraint and anti-theft rules, breach of fiduciary duty, breach of federal, state and local laws prohibiting employment discrimination, and violation of federal and state antifraud laws. Mediation and arbitration can potentially help the parties to the dispute to achieve more mutual goals in these struggles of doctors.

A well-drafted arbitration clause in organizational professional practice documents or other contracts documenting business agreements between doctors may require the appropriate type of professional knowledge on the part of the arbitrator (including a certain number of years of experience in the role of arbitrator and/or healthcare cases) and a hearing within a few months of sharing the necessary documents and information, but without the lengthy prudent disclosure process that often prolongs and raises costs of a litigation in court. When business arbitration is properly conducted by an experienced arbitrator, it should almost always be faster and less expensive than comparable litigation in court.

Mediation in healthcare disputes is particularly well-adapted to focusing the parties to dispute on actual business disputes to be resolved and away from the inevitable feelings of hurt and sometimes exaggerated mutual claims of personal and professional error. Mediation is private and confidential. It can result in a friendly end to a business relationship or solution, and perhaps a reorientation of those relationships through negotiated results that often do not occur through the legal system. Both points are occasionally taken separately in cases of litigation between doctors. Finally, mediation is successful in dealing with a very high proportion of cases where it is tried.

However, since mediation leads to a solution only when the parties involved agree on the outcome, it is not too

${ }^{24}$ D. Charles, 2009, pp. 1-49 (e-source). 
simplistic to say that, contrary to a court procedure where the basic business decisions of the parties involved are taken by a judge or jury, in mediation the parties themselves decide on the outcome.

\section{Conclusion}

Mediation in the Republic of Slovenia has undergone an incredibly rapid development in the last decade, which unfortunately does not apply to the field of mediation in health care. Mediation in health care really is a new method of dispute resolution, but in the last two years, the managements of healthcare institutions and healthcare professionals have considered mediation as a very desirable and indispensable method that will surely experience rapid development in the coming years.

The potential savings depend on the early use of mediation in the procedure. Plaintiffs' attorneys have an understandable resistance to advocating for mediation without first fully examining cases regarding the success in litigation and the amount of litigation costs. Doing otherwise would potentially risk professional negligence because they would not do everything they could for their client. Neither the defendants nor the courts can force the plaintiffs to use mediation. Where plaintiffs receive expert advice that mediation may bring little benefit, they may decide to use it and delay it to avoid the cost of litigation. There is no evidence to suggest that the introduction of mandatory mediation would change this situation. Mediation is therefore at risk of increasing costs.

A patient, who considers that he or she is denied any right granted to him under the said law, is entitled to a hearing of the alleged infringement, first by the provider of health care. If no agreement is reached at this stage on how the dispute can be resolved, the patient may file a request for the consideration of the denial of his right to the Commission of the Republic of Slovenia for the Protection of Patient Rights. At this stage, the legislator offers mediation as one of the potential ways to resolve the dispute between the patient and the healthcare provider. Sometimes, in practice, the resolution of conflicts through mediation was not realized due to the fact that the legislator envisaged mediation at a relatively late stage of the conflict when it was already intensified.

Regardless of the possibilities offered by the legislation in the Republic of Slovenia, mediation began to develop under the auspices of the Association of Health Institutes of Slovenia. The Association is aware that disputes are an integral part of work environments and have a strong impact on the quality of work and the well-being of health care providers and users. Therefore, it seeks to introduce mediation as a validated good method for the healthcare environment. In the field of mediation, the Association adopted the vision of establishing a Centre for Communication and Mediation in Health Care (hereinafter referred to as the Centre), which became operational in $2010 .{ }^{25}$ Within the framework of mediation, the Centre offers advice, assistance and guidance to its members regarding the use of mediation to resolve conflicts in the healthcare sector. In 2011, it also started to provide mediation services available at the headquarters of the Centre and also at individual healthcare facilities outside the Centre (the "on-site mediator concept"). The Centre also provides education and training specific to the field of health care, offering training for the acquisition of mediation skills and education for obtaining the title of "healthcare mediator", which are attended by management workers of healthcare institutions and other healthcare professionals and associates. In 2012, the Centre upgraded its existing activities with an organized model of mediation training and mediation services for its clients. ${ }^{26}$

In the USA, at least three organizations (JAMS, American Arbitration Association and AHLA - American Health Lawyers Association $)^{27}$ offer specialized panels of mediators and arbitrators in the healthcare field, and the healthcare industry is slowly adopting alternative dispute resolution. There are many possible explanations for why alternative dispute resolution is underutilized in health care. One possible explanation is that healthcare attorneys as a group may not have the same opportunities for the contact with mediation and arbitration as full-time litigation counsellors (e.g. in the field of employment, construction, insurance and family law) who may participate in ten or more mediations or arbitrations per year. Many healthcare attorneys are "specialists" in every respect, but they are often "healthcare specialists" who work with their clients in a variety of regulatory and transactional legal matters and court procedures. Other healthcare attorneys, especially in the field of healthcare frauds, start their practice in health care after years of practice prosecuting white collar crime and defending clients, so they have little experience in alternative dispute resolution.

Some private attorneys in the field of frauds are sceptical of government agencies being genuinely interested in mediating fraud cases, although informal discussions with private and government attorneys reflect both genuine interest and good experience on the part of the federal government and state governments in the mediation of relevant

\footnotetext{
25 Mediation in Healthcare, 2012, p. 28 (e-source).

26 Ibid, p. 28.

${ }_{27}$ We AreAHLA, 2015 (e-source).
} 
healthcare fraud cases.

\section{Sources and Bibliography}

BALCERZAK, Gary A. in LEONHARDT, Kathryn K., Alternative Dispute Resolution in Healthcare, A Prescription for Increasing Disclosure and Improving Patient Safety, 2008. URL: http://psqh.com/julaug08/resolution.html 12. 1. 2020.

DOYLE, Charles, QUI Tam: The False Claims Act and Related Federal Statutes Charles. V: American Public Law, August 6, 2009 https://fas.org/sgp/crs/misc/R40785.pdf12. 1. 2020.

KING v. Burwell could have gutted Obamacare in 34 states. Vox. 2015. URL: http://www.vox.com/cards/obamacaresubsidies-lawsuit/what-is-the-case 12. 1. 2020.

MARINER, Wendy K., Standards of Care and Standard Form Contracts: Distinguishing Patient Rights and Consumer Rights in Managed Care, 15 J. Contemp. Health L. \&Pol'y 1, 1999, str. 1-57.

URL: http://scholarship.law.edu/jchlp/vol15/iss1/3 23. 1. 2020.

MEDIACIJA. ZDRZS. 2015. URL: https://zdrzz.si/index.php?option=com_content\&view=article\&id=18\&Itemid=119 23. 1.2020.

MEDIATION in Healthcare. HOPE. 2012.

URL: http://www.hope.be/05eventsandpublications/docpublications/91_mediation/91_HOPE_PublicationMediation_December_2012.pdf 25.12.2019.

MEDIOS. 2015. URL: http://www.medios.si/ 5. 1. 2016.

NOVAK, Janez, Delovnispori, Ljubljana: GV založba, 2004.

PATIENT Protection and Affordable Care Act. Wikipedia 2015.

URL: https://en.wikipedia.org/wiki/Patient_Protection_and_Affordable_Care_Act\#cite_note-13\#cite_note-13 12. 1.2020.

PEČARIČ, Mirko, Širšaprocesnalegitimacijazopernezakonitejavnofinančneugodnosti v imenutožnika in države. V: Pravnik. 2011, let. 66 (128), št. 1-2, pp. 69-86.

SYLLABUS, King et al., V. Burwell. Supreme Court of the United States. 2014.

URL: http://www.supremecourt.gov/opinions/14pdf/14-114_qol1.pdf 12. 1. 2020.

THE FALSE CLAIMS ACT ("FCA"). 2015. URL: https://www.govinfo.gov/app/details/USCODE-2011title31/USCODE-2011-title31-subtitleIII-chap37-subchapIII-sec3729/context

WE Are AHLA. AHLA. 2015. URL:https://www.americanhealthlaw.org/about-ahla12. 1. 2020.

(URS) USTAVA RepublikeSlovenije. Uradni list RS, št. 33/1999 (Constitution of the Republic of Slovenia).

(ZARSS) ZAKON o alternativnemreševanjusodnihsporov. Uradni list RS, št. 97/2009 s kasnejšimisprem. in dopol (Act on Alternative Dispute Resolution in Judicial Matters).

(ZDSS-1) ZAKON o delovnih in socialnihsodiščih. Uradni list RS, št. 2/2004 s kasnejšimisprem. in dopol. (Labour and Social Courts Act).

(ZMCGZ) ZAKON o mediaciji v civilnih in gospodarskihzadevah. Uradni list RS, št. 56/2008 (Mediation in Civil and Commercial Matters Act).

(ZPacP) ZAKON o pacientovihpravicah. Uradni list RS, št. 15/2008 (Patients' Rights Act).

PRAVILNIK o mediaciji v zdravstvu. Uradni list RS, št. 77/2008 (Rules on healthcare mediation).

PRAVILNIK o nagradi in povračilupotnihstroškovmediatorjem, kidelujejo v programihsodišč. Uradni list RS, št. 22/2010, 35/2013 (Rules on awards and reimbursement of travel expenses of mediators, acting in the programs of the courts).

STATUT združenjazdravstvenihzavodovSlovenije. Uradni list RS, št. 5/1993, s kasnejšimisprem. in dopol. 